\title{
Negative Regulation of Immune Cell Destruction
}

National Cancer Institute

\section{Source}

National Cancer Institute. Negative Regulation of Immune Cell Destruction. NCI

Thesaurus. Code C40728.

Any process that decreases the frequency, rate or extent of apoptosis in leukocytes. 